\title{
STUDENTS' SATISFACTION WITH LEARNING EXPERIENCE IN COVID-19 IMPOSED VIRTUAL EDUCATION ENVIRONMENT
}

\author{
SATISFACCIÓN DE LOS ESTUDIANTES RESPECTO A LA EXPERIENCIA \\ DE APRENDIZAJE EN EL ENTORNO EDUCATIVO VIRTUAL IMPUESTO \\ POR COVID-19
}

\section{Marijana Prodanović ${ }^{*}$, Valentina Gavranović ${ }^{2}$}

\author{
Singidunum University, Belgrade, Serbia \\ 1.* Email: mprodanovic@singidunum.ac.rs (D) https://orcid.org/0000-0002-4413-5535 \\ 2. Email: vgavranovic@singidunum.ac.rs (D) https://orcid.org/0000-0002-3011-8769
}

Como Citar: Prodanović, M., \& Gavranović, V. (2021). Students' satisfaction with learning experience in Covid-19 imposed virtual education environment. Revista Publicando, 8(29), 124-131. https://doi.org/10.51528/rp.vol8.id2190

\begin{abstract}
RESUMEN:
La organización del proceso global de enseñanza y aprendizaje durante la pandemia en curso ha sacado a la luz una compleja gama de características educativas que deben tenerse en cuenta al reexaminar y reevaluar la calidad de las prácticas docentes. El criterio ineludible y relevante para crear un contexto educativo significativo incluye las perspectivas y pensamientos de los estudiantes sobre estas facetas de los procesos de los que son participantes activos. Este artículo se centra en la satisfacción de los estudiantes universitarios con diversos aspectos de la organización de la enseñanza y el aprendizaje en línea. Informa sobre las respuestas que los encuestados, estudiantes de la especialidad de inglés, dieron a la Encuesta de Satisfacción de los Estudiantes, que consistía en un conjunto de preguntas de escala Likert de cinco puntos y una abierta. El objetivo de este estudio es investigar el grado de satisfacción de los estudiantes universitarios con el contexto de enseñanza-aprendizaje en línea - su organización general y la calidad de las clases organizadas, impartidas y evaluadas en un entorno virtual. Los resultados de una serie de preguntas cerradas se representan con datos estadísticos y van seguidos de la narración descriptiva, y las respuestas a las preguntas abiertas se clasifican según un denominador común, y posteriormente se analizan y discuten. El análisis de las respuestas muestra que la mayoría de los estudiantes tiene una actitud bastante positiva hacia el entorno de aprendizaje en línea, y también señala las facetas que pueden mejorarse.
\end{abstract}

\section{Palabras Clave:}

Satisfacción de los estudiantes, experiencia de aprendizaje en línea, nivel terciario, COVID-19.

\section{ABSRTACT:}

The organisation of the overall teaching and learning process during the ongoing pandemic has brought to light a complex range of educational features which need to be considered while reexamining and reevaluating the quality of teaching practices. The unavoidable criterion relevant for creating a meaningful educational context includes students' perspectives and thoughts on these layers of the processes they are active participants of. This paper focuses on university students' satisfaction with various aspects of online teaching and learning organisation. It reports on the answers the respondents, students majoring in English, gave to the Student Satisfactory Survey, which consisted of a set of five-point Likert scale and one open-ended questions. The aim of this study is to investigate how satisfied the university students are with the online teaching-learning context - its overall organisation and the quality of lectures organised, delivered and assessed in a virtual environment. The results to a set of closed-ended questions are represented with statistic data and followed by the descriptive narrative, and the answers to the open-ended question are classified according to a common denominator, and subsequently analysed and discussed. The answers analysis shows that the majority of students have a rather positive attitude towards the online learning environment, and it also points to the facets which can be improved.

\section{KEYWORDS:}

Students' satisfaction, online learning experience, tertiary level, COVID-19. 


\section{INTRODUCTION}

$\mathrm{T}$ he ongoing Covid-19-imposed pandemic has severely affected the ways in which we live, communicate and learn. Hardly is there any individual who has not experienced online environments, either for the purpose of business, everyday life or studying. All the stakeholders in the area of education had to uproot many of the models that had previously been used and to replace the traditional classroom with a virtual one. In that respect, it is worth noting that there are still schools which have not reopened in the meantime, i.e., have totally changed their practices since the beginning of 2020 .

The newly created educational environment has provoked much debate and resulted in a body of research studying different aspects, advantages and challenges the online context imposes. The focus of the investigations was on various statistical data, reexamination of teaching practices, methods and techniques, attitudes of all stakeholders, directly or indirectly involved in educational processes. Students' opinions and attitudes have also been taken into consideration as a relevant criterion for planning, organising and conducting educational processes.

This paper investigates students' satisfaction with online teaching and learning organisation, online teaching methods and practices they were exposed to, their learning experience and academic progress. The results and conclusions of the study are drawn from the answers obtained from the Students' Satisfaction Survey - a set of five-point Likert scale questions and one open-ended question. The aim of this study is to investigate which aspects of virtual teaching and learning environment the respondents, 87 students majoring in English at a private university in the Republic of Serbia, are satisfied with, to what extent, and which areas are identified to be improved.

\section{NEW EDUCATIONAL CONTEXT THEORETICAL PERSPECTIVE}

Unfortunately, the wreckage we have been exposed to for over a year has not yet been left behind, despite the efforts being invested by policy-makers round the globe. A number of surveys addressing the effects of the pandemic have confirmed that as much as $89 \%$ of the global student population has faced classroom closure (it was confirmed that in March 2020, shortly after the outbreak, around 1.5 billion students in 185 countries across all the continents experienced the sudden shift from traditional to 'new-normal' education, Petrie et al., 2020), which raised innumerable questions concerning virtual language environment potential - while some existing DLS platforms have reached their full potential, some new have also been designed and activated. It could be said that they have all found common ground that being adequate maintenance, skillful management, i.e., technical equipment provided and proper training of all the participants (Altbach \& De Wit, 2020).

The role of digitalization in education is not a novel one - it has been there since PCs first started being used, via a number of devices and applications which have proved to be very helpful in classrooms around the globe, and used as a complementary means to face-to-face instruction (Bloch, 2013). Apart from mere usage of technological devices for the production of language material, both language learners and instructors have started relying on some world-wide popular apps aimed at language acquisition/learning, such as: Duolingo, Rosetta Stone, Hello Talk, Babbel, Busuu, Memrise, HiNative and many more. Moreover, complete blended courses have been on offer at innumerable universities for decades, providing students with more flexibility, primarily in terms of time management. During the several previous decades, numerous MOOC (massive open online courses) platforms and OER (open education resources) databases, were introduced, to support new educational trends. Despite being fully aware of all the possibilities of the ICT application in practice, and despite a number of professional training sessions available, it appears that no sooner the pandemic broke out than we have all started familiarising ourselves with the virtual learning environment (VLE). Namely, back in 2015, around 60\% of higher education institutions in the USA did not consider introducing any MOOCs, as a part of their common practices (Allen et al., 2016, p. 6), through the open access resources had already been recognised as a means by which institutions around the globe could 'contribute worldwide', in the form of the 'New Learning' approach (García-Sánchez, 2016, p. 491).

Nowadays, the benefits of digital tools cannot be neglected, there are still many questions related to pedagogy of online instruction. A body of research available at the moment has proved rather positive attitudes of both teachers and students about online mode. Prodanovic and Gavranovic (2020) examined the views of English majoring students' on comparison between traditional and online language classrooms, with specific reference to acquiring receptive and productive language skills. The research confirmed the efficiency of new technologies and the fact that Generation $\mathrm{Z}$ representatives have easily accommodated themselves to the new environment.

In a similar vein, Prodanovic (2020b) addressed both language teachers and students' experiences regarding digital learning and assessment surrounding, supported by a number of both synchronous and asynchronous tools and 
applications. She discovered that both ESP and EAP teachers and students feel comfortable while engaged in online activities, including those referring to assessment but also that there is still room for improving practices especially when it comes to assessing productive language skills.

A survey conducted by MacIntyre, Gregersen and Mercer (2020) analysed the attitudes of 634 language teachers, coming from Europe (51.4\%), North America (23.5\%), Asia (8.8\%), South America (6.9\%), and the Middle East (5.2\%), in terms of coping with additional stressors caused by the forced conversion to online teaching and illustrated some correlations between the strategies used and psychological outcomes. Language teachers proved to be very skilled at applying a spectrum of coping strategies.

Similarly, the stands of university language teachers in China, in response to the disruption of the planned activities and ICT literacy, were illustrated by Xingzhen and Jun (2020), who validate their flexibility in adapting to the newly-created needs characterised by the imposed restrictions.

In a recent study, Maican and Cocorada (2020) revealed that Foreign Language Enjoyment (FLE) and strong teacher-student bonds are achievable in an online learning environment. The above-stated was proved on a sample of university students at a comprehensive university in Romania. The situation in the country, as regards students' outlook on online teaching-learning practices in the area of higher education, was also described by Coman et al. (2020), who pointed to the needs for improvement primarily in terms of technological infrastructure and teacher training, which would lead to more successful activities.

\section{RESEARCH CONTEXT AND METHODOLOGY}

This paper investigates students' satisfaction with different online teaching and learning aspects the respondents experienced during the period of six months. The research reports on the results obtained from the Students' Satisfaction questionnaire delivered to 87 respondents, university students majoring in English at a private University in the Republic of Serbia. Due to the outbreak of the COVID-19 pandemic, in the spring of 2020, the activities went online and the students first had a three-month experience on the online education platform Google Meet, during the spring term of the academic year of 2019/2020. After the summer break, the new academic witnessed the support by a new platform - the MS Teams one, which enables synchronous lectures with the possibility for students to actively participate in real-time mode, as well as sections containing learning materials, announcements and chat, thus allowing students to communicate with the teachers via both written messages and video calls.

The questionnaire applied for the purpose of this research consists of two sets of questions whose aim is not only to evaluate the quality of online classes but also to diagnose what could be improved in future planning. The first section includes 9 five-point Likert scale questions which measure students' level of satisfaction with the quality of the organisation and delivery of online classes and assessment portions, communication and support the teachers provide, and the respondents' academic achievement. Another section includes one open-ended question intended for comments and opinions related to any aspect of online teaching and learning the students wanted to mention. The open-ended question was incorporated in the questionnaire with the aim to give the respondents the opportunity to reflect on any aspect they find relevant. In this way, the preconceived ideas related to various characteristics of online education, which might represent the examiners' knowledge, could be avoided. Consequently, the possible answers obtained in this section can shed light on the nature of online teaching and help the examiners get a deeper insight into its various and complex aspects, which altogether can contribute to more qualitative lesson planning and delivery in the future.

The results obtained from the five-point Likert-scale questions are shown in a table and the overall students' satisfaction is illustrated with a chart. The answers to the open-ended question are first analysed inductively and subsequently categorised into groups sharing some common denominator. The results and answers are compared and discussed and pedagogical implications are drawn from the conclusions.

\section{RESEARCH RESULTS ANALYSIS AND INTERPRETATION}

Table 1 lists the research questions the respondents gave their answers to (Q1-Q9), and the numbers in the columns 1 to 5 indicate how many students circled the given option. The provided answers are marked from 1 to 5, whereby 1 denotes "very dissatisfied", 2 is the value for "dissatisfied", 3 for "neither satisfied nor dissatisfied", 4 for "satisfied", and 5 for "very satisfied". The final column represents the mean value calculated for each question. 
Table 1

Questions from the questionnaire, the number of answers and the mean value

\begin{tabular}{|c|c|c|c|c|c|c|c|}
\hline & Question & 1 & 2 & 3 & 4 & 5 & Mean \\
\hline Q1 & How satisfied are you with the availability of learning material? & 9 & 11 & 17 & 17 & 33 & 3.62 \\
\hline Q2 & How satisfied are you with teaching-learning dynamics? & 8 & 8 & 15 & 27 & 29 & 3.7 \\
\hline Q3 & How satisfied are you with teacher-student communication? & 11 & 6 & 7 & 17 & 46 & 3.91 \\
\hline Q4 & $\begin{array}{l}\text { How satisfied are you with the availability of the needed information (schedules, } \\
\text { announcements, etc.)? }\end{array}$ & 10 & 9 & 14 & 13 & 41 & 3.76 \\
\hline Q5 & $\begin{array}{l}\text { How satisfied are you with teaching methods used (principles and practices teach- } \\
\text { ers apply to teach) }\end{array}$ & 13 & 6 & 6 & 29 & 33 & 3.72 \\
\hline Q6 & How satisfied are you with teachers' feedback (in-class and test-related)? & 13 & 6 & 9 & 21 & 38 & 3.75 \\
\hline Q7 & How satisfied are you with organisation and delivery of tests? & 10 & 11 & 10 & 19 & 37 & 3.71 \\
\hline Q8 & $\begin{array}{l}\text { How satisfied are you with your personal (academic and language-related) devel- } \\
\text { opment? }\end{array}$ & 8 & 9 & 19 & 22 & 29 & 3.86 \\
\hline Q9 & $\begin{array}{l}\text { How would you describe your overall experience related to teaching and learning } \\
\text { in the online environment? }\end{array}$ & 7 & 13 & 10 & 29 & 28 & 3.67 \\
\hline
\end{tabular}

The analysis of the results shows that the students' satisfaction span related to various online teaching and learning aspects ranges from 3.62 to 3.91 , which along with the overall satisfaction result of 3.67 represents a rather consistent attitude expressed towards the online education modality.

The results show that the respondents' satisfaction is the lowest in terms of the availability of learning materials, and the mean value amounts to 3.62 , while their satisfaction related to the availability of information referring to various schedules and announcements is somewhat higher and the calculated mean value is 3.76 .

Pertaining to the respondents' satisfaction with the organisation and delivery of lectures, the results show a higher mean value - 3.7 for teaching-learning dynamics and almost the same score (3.72) for the teaching methods the teachers used and applied in the online environment.

The results also show that the students' satisfaction regarding testing - the organisation and delivery - is in com- pliance with their satisfaction with the organisation and delivery of lectures, and its mean value is 3.75 .

The highest mean value obtained from the results relates to the respondents' satisfaction with teacher-student communication, and it amounts to 3.91. A more specific type of teacher-student communication regards the feedback, in-class and test-related, the teachers provided the students with, and the mean value for this question is somewhat lower - amounting to 3.75 .

The only question referring to self-reflection and self-evaluation made the students think about how satisfied they were with their personal - academic and language-related development, and the mean value obtained from the results is also high -3.86 .

The last question belonging to the five-point Likert scale section summarises the overall students' satisfaction with the experience related to the teaching and learning in the online environment, and the results are illustrated in Chart 1. 


\section{Chart 1}

Students' overall satisfaction with the online teaching and learning experience

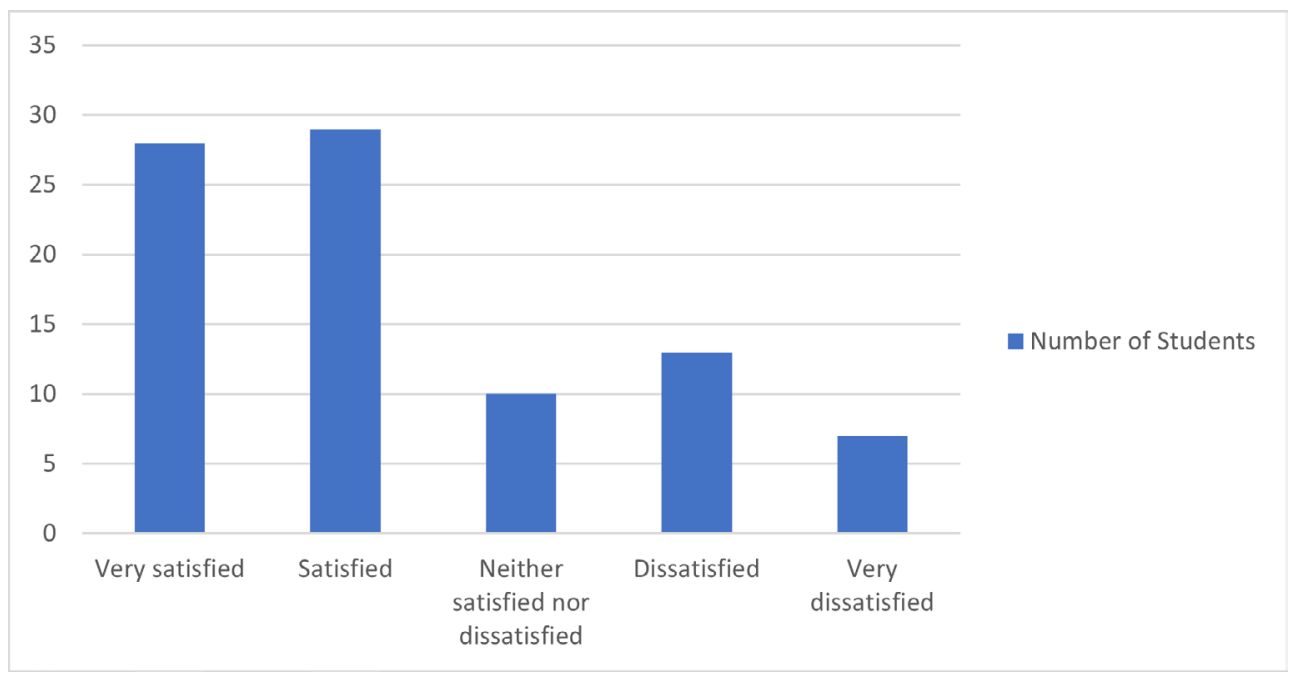

The chart shows that the majority of students expressed a positive attitude towards the online teaching and learning delivery mode, while there are 20 students who are less satisfied with this type of education model. The mean value summing up the overall students' satisfaction with the online teaching and learning experience is among the lowest -3.67 .

The last question from the Students' Satisfaction Questionnaire was open-ended and the respondents could add their thoughts and comments on any specific likes or dis- likes, i.e., any points they wanted to highlight. The answers the respondents provided were analysed and described either as positive or negative.

Table 2 shows comments containing students' positive attitudes towards the online delivery mode, and these are further categorised into several groups according to a common denominator they share. The numbers in brackets designate how many students wrote the same or similar answer grouped within the same type.

Table 2

Answers expressing positive attitudes towards the online learning experience

\begin{tabular}{|c|c|}
\hline Type & Examples of answers \\
\hline General opinion (16) & 'everything is fine', 'I am very satisfied', 'perfect'; \\
\hline Organisation (7) & 'high quality of overall organisation' \\
\hline Education platform (4) & 'Teams platform works nicely', 'everything is user-friendly' \\
\hline Convenience (6) & $\begin{array}{l}\text { 'we can easily obtain all the necessary information', 'ideal } \\
\text { opportunity for students who live in the countryside,' 'ideal } \\
\text { opportunity for working students' }\end{array}$ \\
\hline Communication (4) & $\begin{array}{l}\text { 'teacher communication is exceptional', 'the feedback that } \\
\text { we receive is great' }\end{array}$ \\
\hline Teaching methods (4) & 'the teaching methods keep the classes very interesting' \\
\hline
\end{tabular}




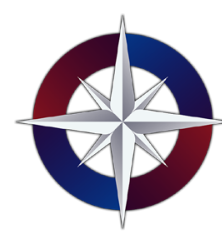

P U B L I C A N D O

I S S N $133900-93304$
Another group of answers the respondents provided is shown in Table 3, and these have some less affirmative connotative meanings in terms of general attitude towards online learning experience.

Table 3

Answers expressing negative attitudes towards online learning experience

\begin{tabular}{ll}
\hline Type & Examples of answers \\
\hline General opinion (4) & 'I do not like online context so \\
& I hope we will be back in the \\
classroom as soon as possible', & 'I prefer learning in a real \\
& classroom', 'I find the old way \\
& of schooling more interactive' \\
& 'I wish we could change our \\
& answers in Mtutor platform', \\
'Sducation platform (3) & finding materials' \\
& 'I had hard time dealing with \\
Technical issues (4) & technical issues' \\
\hline
\end{tabular}

There were also four students who wrote either 'I have no comment' or 'I have nothing to add' for the last question.

\section{DISCUSSION AND PEDAGOGICAL IMPLICATIONS}

The analysis of the results obtained from the five-point Likert scale questions shows a rather consistent attitude of the respondents towards various aspects of their online learning experience. The mean value for all questions ranges from 3.62 to 3.91 , and these values point to the fact that there are no significant deviations related to students' satisfaction with any particular online teaching and learning aspect. The lowest mean value was derived for the availability of learning material and the students were the most satisfied with the communication the teachers had established. All other aspects related to the quality the University and the teachers provided were assessed in a rather similar manner - with the average mean value of around 3.7, which indicates that the students' overall satisfaction with the online delivery mode is close to 'satisfied' attitude.

The only question which contained reflection and self-evaluation asked the students to assess how satisfied they were with their personal development - academic and language-related, and the mean value for this was among the highest, amounting to 3.86. In this manner, the students expressed the opinion that the outcome of their learning in such an education context is rather satisfactory and supports the positive sides of all other aspects investigated in this research.

Even though the average mean value is high, still, twenty students (almost 23\%) assessed their overall attitude towards their online learning experience as negative, opting for either 'very dissatisfied' or 'dissatisfied'. A very consistent attitude, and similar percentage were expressed for all the other questions. The comments the respondents provided in the last, open-ended question can clarify this negative attitude to some extent. Namely, only six students provided reasons for their dissatisfaction, and these are related to giving preference to in-person classes - they explicitly stated that they are eager to get back to the classroom and that they do not like the online delivery mode. Another reason relates to the platform used and difficulties with navigating through all its sections. Closely related to this reason is the one which refers to technical issues - students expressed their dissatisfaction with their own technical support - the lack of information and digital literacy on the one hand, and the Internet connection on the other.

The analysis of the answers the respondents provided for the last, open-ended question also reveals some other aspects encompassed by the nature of the online education context. The comment 'high quality of overall organisation in the period of global health crisis' reveals the important aspect the online environment caters for - health safety. The health care issue within the education framework has never been so emphasised and prioritised as in the COVID-19 era, and it also can affect students' overall satisfaction with the online learning experience. Another issue arising from the results obtained from the Students' Satisfaction Questionnaire pertains to the convenience and availability of education for those students who live in other parts of the country or are employed and cannot attend in-person classes regularly. The online delivery mode allows these students to attend classes wherever they live - and, thus, can make higher education available to those who would not otherwise be able to afford to attend these classes in-person due to economic factors. Another very important aspect relates to more flexible options given to working students - online organisation of classes can support life-long learning and motivate many to continue with their education and coordinate it with work.

The results obtained from the questionnaire show that the university students in this research express a high degree of satisfaction with the online education modality. Such an affective attitude can be utilised in planning and organising a more qualitative educational process. The answers the re- 
spondents provided show that teaching methods and techniques, as the foundation of well and thoroughly planned teaching practices, are perceived as satisfactory by almost $72 \%$ of the students. Such a high percentage shows that the teaching and learning process, lying on the main premises that its final goal is the outcome of learning, can be adapted to the online delivery mode, with certain modifications resulting from the setting of the online environment. On the other hand, the results also show that there is a considerable number of students whose needs have not been met with the online organisation of the educational process, and that they assessed all aspects mainly negatively. When asked to add any comments, the students who expressed negative attitudes did not list many reasons which could significantly contribute to the final conclusions on what could be improved. The only remarks they made refer to some technical difficulties, dissatisfaction with the used educational platform and remarks related to dissatisfaction with the online learning modality in general and giving preference to the face-to-face lesson delivery.

Nonetheless, the results of this research show that, despite the deeply-rooted beliefs that teaching and learning foreign languages, particularly language skills, is best realised through in-person classes, the students of the 21 st century do not see the online environment as an obstacle for reaching their language learning goals. Consequently, what needs to be done is to investigate how to improve the quality of the overall organisation and lesson delivery, particularly how to adapt teaching methods and techniques to the online environment with the aim to reach the learning outcomes in the most effective way.

\section{CONCLUSION}

As a result of the COVID-19 outbreak, educational institutions worldwide responded to the newly created situation in different ways, using different organisational models and strategies. The online teaching and learning environment became the most dominant modality overnight, and changes resulting from this sudden switch from the traditional, thousands of years old face-to-face teaching exerted influence on many - among which teachers and students were the most affected. The process of sudden adaptation started without any prior preparation and planning; it was imposed on both teachers and students, many of whom had never had any experience in teaching and learning online.

This study examined the degree of students' satisfaction with their online learning experience. The study was conducted among a group of undergraduate students majoring in English after six months of studying supported by online educational platforms. The respondents took a satisfaction survey consisting of 9 five-point Likert scale questions and one open-ended question whose aim was to collect comments or thought the students might have had related to their online learning experience. This study aimed at collecting data related to students' satisfaction with various aspects of their learning experience and to identify areas which could be improved.

The analysis of the respondents' answers showed that the overall students' satisfaction is rather high, and that almost two thirds of the students have a positive attitude towards online delivery mode. The results also show that there is a consistent mean value calculated for all questions - relating to the organisation, availability of material and necessary information, teaching methods and dynamics, testing, communication and students' satisfaction with their academic progress - and that none of them significantly stands out as the most or least favourable. The analysis of the respondents' answers reveals that the students are either satisfied with everything related to the online teaching and learning context or dissatisfied. The open-ended questions did not reveal much information about what caused unsatisfactory experience - only several comments related to technical issues and the general dislike of online education. On the other hand, positive comments revealed some relevant advantages pertaining to the availability of higher education for students who are employed or live in the countryside.

Although students' attitudes and satisfaction with their learning and education are relevant factors in the process of planning and organising teaching, it is also important to obtain objective criteria for assessing the effects of certain delivery modes. Therefore, there is space for further investigation on the compliance between students' satisfaction and learning outcomes in order to gain a more objective and comprehensive picture of the effectiveness of the application of online teaching modality. 


\section{REFERENCES}

Allen, I. E., Seaman, J., Poulin, R., \& Straut, T. T. (2016). Online report card: Tracking online education in the United States. Babson Survey Research Group. http://onlinelearningsurvey.com/reports/onlinereportcard.pdf

Altbach, P. G., \& De Wit, H. (2020). Postpandemic outlook for higher education is bleakest for the poorest. International Higher Education, 102, 3-5. https://doi. org/10.36197/IHE.2020.102.01

Bloch, J. (2013). Technology and ESP. In: B. Paltridge and S. Starfield (Eds.), The Handbook of English for Specific Purposes (pp. 429-447). Wiley-Blackwell, 429-447. https://doi.org/10.4000/asp.3806

Chen, X. (2016). Evaluating Language-learning Mobile Apps for Second-language Learners. Journal of Educational Technology Development and Exchange, 9(2), Article 3. https://doi.org/10.18785/ jetde.0902.03

Coman, C., Ṭîru, L., Meseșan-Schmitz, L., Stanciu, C., \& Bularca, M. (2020). Online Teaching and Learning in Higher Education during the Coronavirus Pandemic: Students' Perspective”. Sustainability, 12(24), 10367. https://doi.org/10.3390/su122410367

García-Sánchez, S. (2016). Ubiquitous interaction for ESP distance and blended learners. Journal of Applied Research in Higher Education, 8(4), 489 - 503. https://doi.org/10.1108/JARHE-04-2014-0052

MacIntyre, P., Gregersen, T., \& Mercer, S., Language teachers' coping strategies during the Covid-19 conversion to online teaching: Correlations with stress, wellbeing and negative emotions. System, 94, 102352. https://doi.org/10.1016/j.system.2020.102352

Maican, M-A., \& Cocorada, E. (2021). Online Foreign Language Learning in Higher Education and Its Correlates during the COVID-19 Pandemic. Sustainability, 13, 781. https://doi.org/10.3390/ su13020781

Petrie, C., Aladin, K., Ranjan, P., Javangwe, R., Gilliland, D., Tuominen, S., \& Lasse, L. (2020). Education disrupted education built. Spotlight: Quality education for all during Covid-19 crisis - Report. HundrEd.
Prodanović, M., \& Gavranović, V. Online language teaching and learning: Anglistics students' perspectives on the new educational environment imposed by the COVID 19 outbreak. Zbornik radova Filozofskog fakulteta u Prištini, 50(3), 231-248. https://doi. org/10.5937/ZRFFP50-27873

Prodanović, M. (2020a). Blended learning: convergence between technology and pedagogy, Zbornik instituta za pedagoška istraživanja, 52(2), $534-541$.

Prodanović, M. (2020b). Testing the Untestable: Humanistic Approaches to Modern-Era Language Testing. ICC Journal, 2(3), 47-51.

Xingzhen, G.L., \& Jun, Z.L. (2020). Teacher Learning in Difficult Times: Examining Foreign Language Teachers' Cognitions About Online Teaching to Tide Over COVID-19. Frontiers in Psychology, 11, 2396. https://doi.org/10.3389/fpsyg.2020.549653

\section{WEBSITES}

https://en.unesco.org/covid19/educationresponse 